\title{
Evaluation of Antibody Production against Newcastle Disease Virus after Immunization with Different Vaccines in Fayoumi Chicks
}

\author{
Shama Ranjan Barua ${ }^{1}$, M Mansurul Amin², Shaiful Islam³ ${ }^{3 *}$ Sukanta Chowdhury4, M Shafiqul Islam Khan ${ }^{5}$ and \\ MAli Asgar ${ }^{5}$ \\ ${ }^{1}$ Advance Animal Health Co Ltd, Maijdy, Noakhali 3800, Bangladesh, ${ }^{2}$ Department of Microbiology \& Hygiene, Bangladesh Agricultural University \\ (BAU), Mymensingh 2202, Bangladesh, ${ }^{3}$ Bangladesh Livestock Research Institute (BLRI), Regional Station, Baghabari, Sirajgonj 6770, Bangladesh, \\ ${ }^{4}$ Bangladesh Extension Education Services (BEES), Kazipara, Brahmanbaria 3400, Bangladesh, ${ }^{5}$ Barishal Government Veterinary College, \\ Babugonj, Barishal 8210, Bangladesh
}

[Received 12 December 2007; Accepted 14 June 2008]

\begin{abstract}
The research work was performed in the experimental sheds and virology laboratory of the Department of Microbiology and Hygiene, Faculty of Veterinary Science, Bangladesh Agricultural University (BAU), Mymensingh during the period from January to November 2006 for the detection of persistence of maternallyderived antibody (MDA) against Newcastle disease virus (NDV) in Fayoumi chicks as well as evaluation of antibody production in chicks after vaccination. Five experimental groups of 110-day-old Fayoumi chicks were vaccinated for comparative study. Group A was vaccinated with baby chick ranikhet disease vaccine (BCRDV, F-strain), group B with Izovac $B_{1}$ Hitchner $^{\circledR}\left(B_{1}\right.$ strain), group C with Cevac New $L^{\circledR}$ (LaSota strain) and group $D$ with Avinew ${ }^{\circledR}$ (VG/GA strain) through intraocular (i/o) route while group $E$ was kept as unvaccinated control. Serum samples obtained from 10 randomly selected birds from each group on the occasion of 7, 13, 15, 17, 19 and 21 days post-vaccination (DPV) were subjected to haemagglutination inhibition (HI) test. It was found that persistence of MDA against Newcastle disease virus (NDV) retained until the age of day 20 in Fayoumi chicks and among the four commercial vaccines, Avinew ${ }^{\circledR}$ (VG/GA strain) appeared to be slightly superior compared to those of BCRDV (F-strain), Izovac $B_{1}$ Hitchner $^{\circledR}\left(B_{1}\right.$ strain) and Cevac New $L^{\circledR}$ (LaSota strain) in respect of $\mathrm{HI}$ antibody response. The $\mathrm{F}$-values of $\mathrm{HI}$ titre among four vaccines were significantly different $(p<0.01)$.
\end{abstract}

Keywords: Newcastle disease virus (NDV), Fayoumi chicks, Maternally-derived antibody (MDA), Haemagglutination inhibition (HI), Newcastle disease (ND) vaccines

\section{Introduction}

Newcastle disease (ND) is a highly contagious viral ailment belonging to Paramyxovirus type 1 of the genus Avula virus, sub-family Paramyxovirinae of the family Paramyxoviridae ${ }^{1}$. Strains of Newcastle disease virus (NDV) are distinguished into five pathotypes $^{2}$ on the basis of the clinical signs in infected chickens and other birds. These are viscerotropic velogenic virus (vvNDV), neurotropic velogenic virus (nvNDV), mesogenic virus, lentogenic virus and asymptomatic enteric viruses.

The disease is kept under control by vaccination and other preventive measures. Vaccination of birds as a means of prevention of ND in Bangladesh is being conducted by the Department of Livestock Services (DLS), Government of People's Republic of Bangladesh and non-government organizations (NGO). Currently practiced vaccination programme against ND includes administration of two types of live vaccines of either lentogenic (F, $\mathrm{B}_{1}$, LaSota strain) or Mesogenic (M-strain) and inactivated (killed) vaccines. Such vaccines and vaccination programme are sometimes found ineffective to protect chickens against $\mathrm{ND}^{3}$. Among the various causes of vaccination failure, the age of birds at the time of vaccination is an important one. The priming time depends on the level of maternally-derived antibody (MDA). In spite of the fact that vaccination is thoroughly followed, incidence of ND with varied degrees has been recorded by different investigators such as $18.65 \%$ by Kamal ${ }^{4}, 4.80 \%$ by Bhattacharjee et al. ${ }^{5}, 17.20 \%$ by Islam et al. ${ }^{6}, 10.24 \%$ by Talha et al. ${ }^{7}, 9.80 \%$ by Saleque et $a .^{8}$, and $19.50 \%$ by Das et al. ${ }^{9}$.

For the control of ND in Bangladesh, vaccines are produced with F strain (lentogenic) and M strain (Mukteswar, mesogenic) by Department of Livestock Services (DLS). Beside these, vaccines containing $\mathrm{B}_{1}$, LaSota, VG/GA strains etc. are imported and marketed in Bangladesh. These are administered under different schedule of primary and followed by either live or inactivated vaccine as a secondary one. The schedule of vaccination however, differs with type of flock such as broiler, layer, parent, and grandparent stock and those reared under backyard system. As

*Corresponding author:

Shaiful Islam, Scientific Officer \& Station Incharge, Bangladesh Livestock Research Institute (BLRI), Regional Station, Baghabari, Sirajgong 6770, Bangladesh Tel (Office): (0751) 63803; Cell: 01712 825447; E-mail: psaifuldvm@yahoo.com 
stated earlier, Fayoumi day-old chicks (DOC) are being kept by rural farmers and are getting priority day-by-day. These farmers required to be encouraged with continuous support of disease preventive measures. As such prophylaxis against ND comes under consideration where the schedule of vaccination demands evaluation on the performance or efficacy of vaccines.

The present research program was undertaken to record the persistence of maternally-derived antibody (MDA) against NDV in Fayoumi chicks, and also to compare the antibody production level to BCRDV (F strains), Izovac $B_{1}$ Hitchner $^{\circledR}$ ( $B_{1}$ strain), Cevac New $L^{\circledR}$ (LaSota strain) and Avinew (VG/GAstrain) in Fayoumi chicks.

\section{Materials and Methods}

\section{Experimental chicks}

A total 110 apparently healthy day-old-chicks of Fayoumi breed were collected from the Government Poultry Farm, Mirpur, Dhaka and carried to the experimental houses of the Department of Microbiology and Hygiene, Bangladesh Agricultural University (BAU), Mymensingh. The birds were supplied with feed (Quality Feed Co Ltd) and water adlibitum maintaining strict biosecurity.

\section{Newcastle disease vaccine (NDV)}

Lyophilized ND vaccines baby chick ranikhet disease vaccine (BCRDV, F-strain, lentogenic), Izovac $\mathrm{B}_{1}$ Hitchner $^{\circledR}$, $\left(\mathrm{B}_{1}\right.$ strain, lentogenic), Cevac New $L^{\circledR}$ (LaSota strain, lentogenic) and Avinew ${ }^{\circledR}$ (VG/GA strain, lentogenic) were collected from local market and were used during the experiment. The vaccines were stored and diluted during use according to the instruction of manufacturers.

\section{Experimental design}

One hundred and ten-day-old Fayoumi chicks were grouped into five groups; viz., A, B, C, D and E, where group A, B, C and D contained 20 birds each and group $\mathrm{E}$ contained 30 birds. Prior to grouping and vaccination blood samples were collected to measure the maternally-derived antibody (MDA) on day 3 and day 7 of age of chicks, which were then divided into five groups $(n=5)$ as required. The birds of group A, B, C and D were vaccinated with BCRDV (F-strain, lentogenic), Izovac Hitchner $\mathrm{B}_{1}{ }^{\circledR}$ ( $\mathrm{B}_{1}$ strain, lentogenic), Cevac New $L^{\circledR}$ (LaSota strain, lentogenic) and Avinew ${ }^{\circledR}$, (VG/GA strain, lentogenic) vaccines respectively through intraocular (i/o) route while birds of group $\mathrm{E}$ was kept as unvaccinated control. The vaccines were administrated at 7 days of age according to manufacturer's direction. Blood samples were collected for sera from 10 randomly selected birds from 4 former group at 7, 13, 15, 17, 19 and 21 days post-vaccination (DPV) and from group $E$ at the age of day 7, 10, 14, 16, 18, 20 and 22 for the determination of haemagglutination inhibition (HI) antibody titre using HI test.

Newcastle disease vaccine virus

Laboratory cultures of $B_{1}$ vaccine virus of Izovac $B_{1}$ Hitchner ${ }^{\circledR}$ was propagated in fertile eggs (embryo of 10-day-old) of Fayoumi chicken and the allantoic fluid was used as antigen for haemagglutination (HA) and haemagglutination inhibition (HI) test. The presence of NDV in allantoic fluid was tested by slide haemagglutination (HA) test ${ }^{10}$.

\section{Slide haemagglutination (HA) test}

Slide haemagglutination (HA) test was performed to determine the presence of NDV in the allantoic fluid of the infected embryos. The clumping of chicken RBC in allantoic fluid appearing within a minute was considered as positive for the presence of virus.

\section{Micro-plate haemagglutination (HA) test}

The test was carried out ${ }^{10}$ by two-fold serial dilutions of the viral suspension in a U-shaped plate to determine 4 HA units (4 HA/25 $\mu \mathrm{l}$ ).

\section{Micro-plate haemagglutination inhibition (HI) test}

The haemagglutination inhibition (HI) test was performed ${ }^{10}$ to determine the $\mathrm{HI}$ titre of the sera samples collected from the chicks. The HI titre of sera samples of control group of chicks was determined to measure the maternal antibody and its persistence. The test was conducted by using constant $4 \mathrm{HA}$ unit antigen and decreasing serum method ( $\beta$ procedure).

\section{Statistical analysis}

The data were analysed by using Statistical Package for Social Sciences (SPSS) program. Differences among the vaccinated groups were determined by F-test.

\section{Results and Discussion}

In the present study persistence of maternally (passive)-derived antibody (MDA) was measured on a number of occasions starting from day 3 until day 22 and the titres are presented in Table 1 . The mean \pm SD of haemagglutination inhibition (HI) titre were $89.60 \pm$ $33.05,108.80 \pm 30.91,198.40 \pm 76.62,96.00 \pm 33.73,64.00 \pm 36.95$ and $41.60 \pm 20.24$ in case of group A; $67.20 \pm 35.22,102.40 \pm 33.05$, $268.80 \pm 183.02,86.40 \pm 45.38,48.00 \pm 16.87$ and $32.00 \pm 18.48$ in case of group B; $54.40 \pm 15.46,99.20 \pm 38.31,172.80 \pm 74.21$, 83.20 $\pm 30.91,59.20 \pm 30.22$ and $40.00 \pm 21.66$ in case of group $C$, and $48.00 \pm 16.87,102.40 \pm 33.05,153.60 \pm 75.12,300.80 \pm 190.93,192.00$ \pm 134.92 and $108.80 \pm 66.10$ in case of group D at 7, 13, 15, 17, 19 and 21 days post-vaccination (DPV) respectively. On the other hand the unvaccinated control group E maintained a mean \pm SD of HI titres of $96.00 \pm 33.73,41.60 \pm 15.46,32.00 \pm 18.48,13.60 \pm$ $3.86,10.40 \pm 5.06,7.20 \pm 3.67,6.00 \pm 2.11$ and $2.60 \pm 0.97$ at the age of day $3,7,10,14,16,18,20$ and 22 respectively.

It was observed that such antibody remains minimal in chicks until the age of day 20 and none at the age of day 22 and afterwards. The finding of this investigation in respect of MDA is closely related with Begum et al. ${ }^{11}$ who stated that MDA remains protective until 18 days of age. On the other hand, Chowdhury et $a .^{3}{ }^{3}$, Islam et al. ${ }^{12}$ and Shil ${ }^{13}$ stated the period of its existence were 12, 15 and 17 days of age chicks respectively. The level of HI antibody titres exists during first two weeks of life ${ }^{14-15}$. However, Balla ${ }^{16}$ and Mahmud ${ }^{17}$ reported that MDA persisted until day 27 of age of chicks but Saeed et al. ${ }^{18}$ found that MDA declined to zero after the age of 25 days of chicks. According to Islam et al. ${ }^{12}$, MDA can be considered as an effective means of protection of the chickens till two weeks of age. 
Immunization against Newcastle Disease in Chicks

Table 1. Results of persistence of maternally-derived antibody (MDA) titre to Newcastle disease vaccine in Fayoumi chicks

\begin{tabular}{|c|c|c|c|c|c|c|c|c|}
\hline $\begin{array}{l}\text { Bird } \\
\text { serial No. }\end{array}$ & \multicolumn{8}{|c|}{ Haemagglutination inhibition titre (HI unit) at different periods } \\
\hline 1 & 128 & 64 & 64 & 16 & 16 & 16 & 8 & 4 \\
\hline 3 & 128 & 64 & 32 & 16 & 16 & 8 & 8 & 4 \\
\hline 4 & 128 & 32 & 32 & 16 & 16 & 8 & 8 & 2 \\
\hline 6 & 64 & 32 & 32 & 16 & 8 & 8 & 4 & 2 \\
\hline 7 & 64 & 32 & 16 & 16 & 8 & 4 & 4 & 2 \\
\hline 8 & 64 & 32 & 16 & 8 & 8 & 4 & 4 & 2 \\
\hline 9 & 64 & 32 & 16 & 8 & 4 & 4 & 4 & 2 \\
\hline
\end{tabular}

$\mathrm{SD}=$ Standard deviation; $\mathrm{HI}=$ Haemagglutination inhibition.

One of the principal objectives of this study was to determine the comparative performance of BCRDV (F strain), Izovac $\mathrm{B}_{1}$ Hitchner ${ }^{\circledR}\left(\mathrm{B}_{1}\right.$ strain), Cevac New $\mathrm{L}^{\circledR}$ (LaSota strain) and Avinew ${ }^{\circledR}$ (VG/GA) in chicks. As such a relative statement of HI antibody titres of sera samples obtained from birds of group $\mathrm{A}$ (vaccinated with BCRDV), group B (vaccinated Izovac $B_{1}$ Hitchner $^{\circledR}$ ), group $\mathrm{C}\left(\right.$ Cevac New $\mathrm{L}^{\circledR}$ ) and group D (Avinew $\left.{ }^{\circledR}\right)$ together with that of non-vaccinated control group E (control) is depicted in Table 2. It may be noted that the mean $\mathrm{HI}$ titres of the four vaccinated groups of birds are more or less of similar order when measured at 7, 13, 15, 17, 19 and 21 DPV. It was observed that the F-value of HI titres among four vaccines was significantly different $(p<0.01)$. Peak level of HI titres was found on 15 DPV in group A, B and C, which is similar to observation of Rahman et al. ${ }^{19}$ where the author stated that HI antibody titres reached the peak levels between 2 to 3 weeks of vaccination.

Among the four vaccines, Avinew ${ }^{\circledR}$ (VG/GA strain) engendered highest HI titres, which is in agreement with the previous work done by Beard et al. ${ }^{20}$ who stated VG/GA strain produced better immunity than $B_{1}$. It is also similar to the findings of Mahmud ${ }^{17}$ who noted that mean HI titres was higher in birds vaccinated with Avinew $^{\circledR}$ (VG/GA strain) than BCRDV (F-strain).

In this study, BCRDV (F strain), Izovac $B_{1}$ Hitchner $^{\circledR}\left(B_{1}\right.$ strain) and Cevac New $L^{\circledR}$ (LaSota strain) produced more or less similar degree of HI titres. In this regard it may be mentioned that Ibrahim et al. ${ }^{21}$ who also compared $\mathrm{F}$ strain of ND vaccine with $\mathrm{B}_{1}$ and LaSota and found no significant difference among these three strains.

The peak HI titre was higher in the group of chicks vaccinated with Izovac $B_{1}$ Hitchner $^{\circledR}$ than BCRDV and Cevac New $L^{\circledR}$ (Table 2). However, BCRDV and Cevac New $\mathrm{L}^{\circledR}$, birds vaccinated with BCRDV (F strain) showed higher HI titre than Cevac New $\mathrm{L}^{\circledR}$ (LoSota strain) though previous result of Shil ${ }^{13}$ indicated that Cevac New $L^{\circledR}$ provide more immunity than BCRDV. In contrast to this, it has been found that LaSota strain gave better immunity than $\mathrm{B}_{1}^{22}$. The lentogenic $\mathrm{F}$ and Lasota strains provided superior antibody production after vaccination compared to $\mathrm{B}_{1}{ }^{23}$. In addition to the antigenic characteristics of the vaccine virus, the titre and the dose of virus play an important role in the level of immunity produced ${ }^{24-27}$.

Table 2. Comparative haemagglutination inhibition (HI) titre in sera of Fayoumi chicks following vaccination with different vaccines

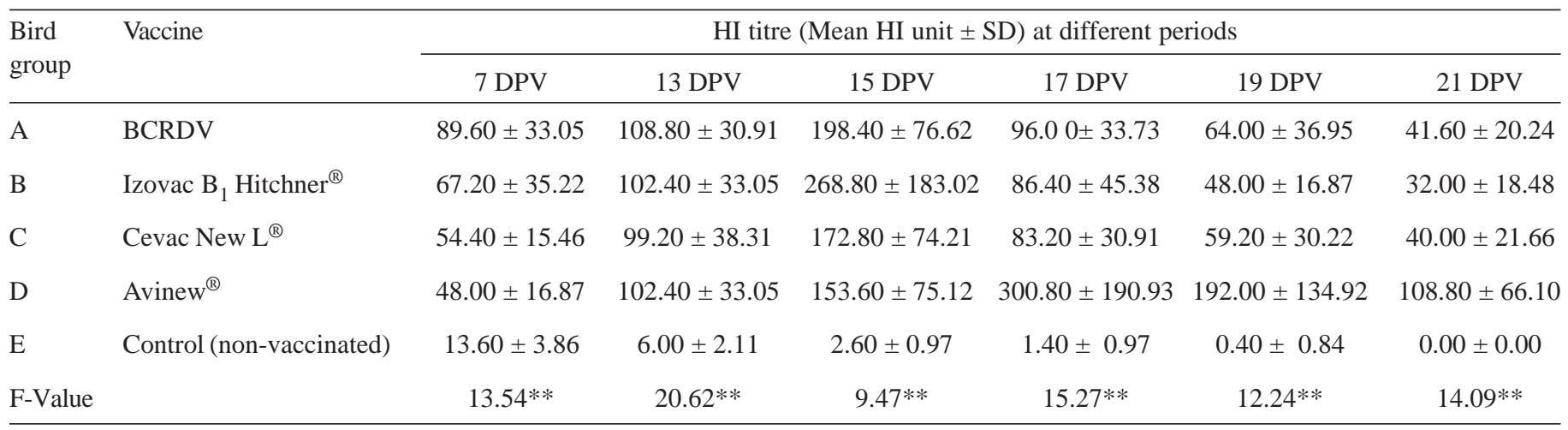

$\mathrm{DPV}=$ Days post-vaccination; $\mathrm{SD}=$ Standard deviation, $* *=$ Significant $(p<0.01)$ 
As regards the prime objectives of the present study, it may be stated that production of $\mathrm{HI}$ antibody was higher in birds of group $\mathrm{D}$ vaccinated with Avinew ${ }^{\circledR}$ compared to those of group A vaccinated with $B C R D V$, group $B$ vaccinated with Izovac $B_{1}$ Hitchner $^{\circledR}$ and group C vaccinated with Cevac New $\mathrm{L}^{\circledR}$ (LaSota strain). However, it was earlier stated that among the lentogenic strains, the LaSota strain is more virulent in the host than $\mathrm{B}_{1}$ or $\mathrm{F}$ and causes more post-vaccination respiratory symptoms ${ }^{28-29}$, whereas $\mathrm{B}_{1}$ was a little more virulent and effective than $\mathrm{F}^{30}$. In the statistical analysis, it was observed that the F-value of HI titres among four vaccines were significantly different $(p<0.01)$.

In view of above, further investigation, as requires to be performed include the influence of maternal immunity in chicks on the efficacy of $\mathrm{F}, \mathrm{B}_{1}$, LaSota and VG/GA strains vaccine, effect of different environmental and climatic condition on the performance of ND vaccines in chickens, and assessment of genetic reversion of $\mathrm{F}, \mathrm{B}_{1}$, LaSota and VG/GA strain after vaccination.

Newcastle disease (ND) is recognized as one of the serious threat to the developing poultry industry in Bangladesh. Vaccination is extensively used to protect birds against ND. Therefore, the types of vaccine, the efficacy of the vaccines and vaccination schedule are important factors for the success of vaccination. Moreover, antigenicity of vaccine virus, virulence of field virus, route of administration of vaccine and age of birds etc. are also considered as a matter of great consequence. To protect the chickens against $\mathrm{ND}$, mostly the lentogenic BCRDV and mesogenic live (RDV) vaccines are mostly used in Bangladesh. Beside these, $\mathrm{B}_{1}$, LaSota, VG/GA, cloned and inactivated vaccines are also imported. Vaccination is an effective control measure relies on two aspects. Firstly vaccination of the parent stock to ensure that the progeny chicks are hatched with a high level of maternally-derived antibody (MDA) and secondly, vaccination of the chickens with a suitable vaccine at the correct age. The resultant high level of MDA found in the progeny chickens is important in protecting the chicken during 10 to 14 days of age from NDV infection. However, as MDA level declines gradually and chickens become susceptible to NDV therefore, immunity must be boosted by secondary vaccination.

\section{References}

1. De Leeuw O \& Peeters B. 1999. complete nucleotide sequence of Newcastle disease virus. Evidence for the existence of a new genus within the subfamily Paramyxovirinae. J Gen Viral. 80: 131-136.

2. Beard CW \& Hanson RP. 1984. Newcastle disease. In Diseases of Poultry (Hofstad MS, Barnes HJ, Calnek BW, Reid WM \& Yoder HW eds), $8^{\text {th }}$ edn, pp 452-470. Iowa State University Press, Ames, Iowa.

3. Chowdhury MSI, Chowdhury TIMFR, Sarker AJ, Amin MM \& Hossain WIMA. 1982. Studies on Newcastle disease in Bangladesh, the role of residual maternal antibody on immune response and selection of an optimum age for primary vaccination of chicks. Bangladesh Vet $J$. 16: $12-22$.

4. Kamal AHM. 1989. Pathological investigation on the mortality of chicken in Bangladesh Agricultural University Poultry Farm. MS Thesis. Department of Pathology, Faculty of Veterinary Science, Bangladesh Agricultural University (BAU), Mymensingh.
5. Bhattacharjee PS, Kundu RL, Biswas RK, Mazumder JU, Hossain E \& Miah AH. 1996. A retrospective analysis of chicken diseases diagnosed at the Central Disease Investigation Laboratory, Dhaka. Bangladesh Vet J. 30: 105-113.

6. Islam MR, Khan MA, Das PM \& Bari AS. 1998. Poultry diseases diagnosed at necropsy in 1997 and 1998 in the Department of Pathology of Bangladesh Agricultural University, Mymensingh. Proceedings of the $5^{\text {th }}$ BSVER Annual Scientific Conference, $3^{\text {rd }}-4^{\text {th }}$ December 1998. Bangladesh Agricultural University (BAU), Mymensingh.

7. Talha AFSM, Hossain MM, Chowdhury EH, Bari ASM, Islam MR \& Das PM. 2001. Poultry diseases occurring in Mymensingh district of Bangladesh. Bangladesh Vet. 18: 20-23.

8. Saleque MA, Rahman MH \& Hossion MI. 2003. Seasonal variation in the prevalence of poultry disease in Bangladesh, pp 23-24. Proceedings of the $9^{\text {th }}$ BSVER Annual Scientific Conference, $6^{\text {th }}-7^{\text {th }}$ January 2003. Shilpachariya Zainul Abedin Auditorium. Bangladesh Agricultural University (BAU), Mymensingh.

9. Das PM, Rajib DMM, Noor M \& Islam M. 2004. A retrospective analysis of proportional incidence of poultry diseases in greater Mymensingh district of Bangladesh. Paper presented to the $4^{\text {th }}$ International Poultry Show and Seminar, March 2005. BangladeshChina Friendship Conference Centre, Dhaka, Bangladesh.

10. Anonymous. 1971. Newcastle disease. In Methods for Examining Poultry. Biologics and for Identifying and Quantifying Avian Pathogens, p 66. National Academy of Sciences, National Research Council, Washington DC.

11. Begum K, Khan MSR, Rahman MB, Kafi MA, Das M \& Mamun SAA. 2006. Investigation on baby chick Ranikhet disease vaccine administration in chicks of vaccinated and nonvaccinated origin. Bangladesh J Vet Med. 4(2): 93-96.

12. Islam MR, Haque QM, Giasuddin M, Alam J \& Rahman MM. 2003. Assessment of maternally derived antibody of commercial flock against Newcastle disease. Proceedings of the $3^{\text {rd }}$ International Poultry Show and Seminar, pp 89-93. Bangladesh-China Friendship Conference Center, Dhaka, Bangladesh.

13. Shil NC. 2006. Evaluation of the antibody production following single vaccination with BCRDV, Izovac $B_{1}$ Hitchner $^{\circledR}$ and Cevac New $L^{\circledR}$ in broiler chicks. MS Thesis. Department of Microbiology and Hygiene, Bangladesh Agricultural University (BAU), Mymensingh.

14. Ibrahim AL, Ideris A \& Babjee AM. 1992. An overview of the use food based Newcastle disease vaccine in Malaysia. In Newcastle Disease in Village Chickens, pp. 75-78. Australian Centre for International Agricultural Research (ACIAR), Canbera.

15. Westbury HA. 1984. Comparison of the immunogenicity of NDV strains $\mathrm{V}_{4}, \mathrm{~B}_{1}$ and LaSota in chickens. 1. Tests in susceptible chickens. Aust Vet J. 61: 5-9.

16. Balla L. 1986. Use of standardized HI test for monitoring immunity to Newcastle disease I. Experiments to standardize the HI test. II. Antibody response after different immunization schedules. Magyar Allatorvosok Lapja. 41: 98-109.

17. Mahmud MS. 2006. Comparative efficacy of Avinew ${ }^{\circledR}$ (VG/GA strain) and BCRDV (F strain) vaccines in broiler chicks. MS Thesis. Department of Microbiology and Hygiene, Bangladesh Agricultural University (BAU), Mymensingh.

18. Saeed Z, Ahmad S, Rizvi AR \& Ajal M. 1988. Role of maternal antibody in determination of an effective Newcastle disease vaccination programme. Pakistan J Vet Res. 1: 18-21.

19. Rahman MB, Rahman MM, Rahman M, Kabir SML, Nazir KHMNH \& Amin MM. 2004. Efficacy of $\mathrm{V}_{4} \mathrm{HR}$ Newcastle disease vaccine in Broiler birds in Bangladesh. Int J Poult Sci. 3: 365-368.

20. Beard CW, Villegas P \& Glisson JR. 1993. Comparative efficacy of the B-1 and VG/GA vaccine strains against velogenic viscerotropic Newcastle disease virus in chickens. Avian Dis. 37: 222-225. 
21. Ibrahim AL, Lai MC \& Aini I. 1983. Spray vaccination with an improved F Newcastle disease vaccine. A comparison of efficacy with the $\mathrm{B}_{1}$ and LaSota vaccines. Br Vet J. 139: 213-219.

22. Creanga E. 1972. The efficacy of B1 fowl pest vaccine. Rev Zootch Med Vet. 22(3): 67-79.

23. Almassyl K, Barhouma N, El-Sabbgh A, Ibrahim SN, Boktor N, Khashaba E \& Gawad SA. 1979. Comparative immunization experiments with lentogenic Newcastle disease vaccine strain. $J$ Egyp Vet Med Assoc. 35: 95-104.

24. Bankowski RA \& Hill RW. 1954. Factors influencing the efficiency of vaccination of chickens against Newcastle disease by the air borne route, pp 317-327. Proceedings of the $91^{\text {st }}$ Annual Meeting of the American Association of Scattle.

25. Crawley JF. 1954. Immunization of chickens against infectious bronchitis and Newcastle disease by the spray method, pp 234-237. Paper presented to the $10^{\text {th }}$ Worlds Poultry Congress, Edinburgh.
26. Crawley JF. 1954. Incidence of Newcastle disease in Canadian poultry flocks during 1952-1953. Can J Com Med 18(4): 128-130.

27. Winterfield RW \& Seadle EH. 1957. The immune response of chickens vaccinated at an early age with $\mathrm{B}_{1}$ Newcastle disease virus administered through the drinking water under field condition. Poultry Sci. 36: 6570 .

28. Allan WH, Lancaster JE \& Tooth B. 1978a. Selection of the vaccine seed strain. In Newcastle Disease Vaccines, Their Production and Use, Chapter 3, pp 10-18. Food and Agricultural Organization of United Nations, Rome.

29. Allan WH, Lancaster JE \& Tooth B. 1978b. Vaccination Programmes. In Newcastle Disease Vaccines, Their Production and Use, Chapter 11, pp 93-102. Food and Agricultural Organization of United Nations, Rome.

30. Bran L, Suhaci I \& Popa C. 1961. Comparison of attenuated Newcastle disease virus strains. $\mathrm{B}_{1}$ and $\mathrm{F}$, methods of vaccination. Lucr Inst Pasteur Buco Bucuresti. 5: 5-20. 